\title{
THE EFFECTS OF REPLACING GROUNDNUT CAKE WITH COTTONSEED CAKE ON THE PERFORMANCE AND CARCASS CHARACTERISTICS OF BROILER CHICKENS
}

\author{
BAMGBOSE, A.M. \\ Animal Production Programme, Abubakar Tafawa Balewa University, P.M.B. 0248, Bauchi, \\ Nigeria. \\ Received 09 February 1996; Accepted 10 October 1996
}

\section{ABSTRACT}

The effects of replacing groundnut cake ( $\mathrm{NNC}$ ) with cottonseed cake (CSC) at 0,50 and $100 \%$ levels in starter and finisher diets on broiler performance, carcass characteristics and gut morphiogy were evaluated in a 56 - day feeding trial. Average daily feed intake, average daily weight gain, and feed/gain ratio were significantly $(P<0.05)$ affected by dietary treatments at the starter and finsiher phases. Higher levels of CSC significantly depressed feed intake and weight gain of birds at the starter finisher phases. Eviscerated weight (E.W) dressing percentage, total edible meat, and abdominal fai pad decreased with increasing level of $\mathrm{CSC}$ while weights and lengths of small intestine, large intestine, caeca and gizzard weight increased significantly $(P<0.05)$ from 0 to $100 \%$ CSC diets. It can be concluded that CSC inclusion at 50 and $100 \%$ level had adverse effect on performance and carcass parameters assessed.

Key Words: Groundnut cake, Cotton seed Cake, performance

\section{INTRODUCTION}

The supply of consumable animal protein is grossly inadequate, this fact has been repeatedly echoed over decades and as long as the situation needs improvements, no amount of emphasis to the effect can be overly laid. Intensive poultry production in Nigeria is hindered by its high dependence on importation of feed raw materials. Such feed ingredients, particularly the plants and animal

Current Address: College of Animal Science and livestock Production, University of Agriculture, P.M.B. 2240, Abcokuta, Nigeria. protein sources are largely imported. Hence the use of locally available feed ingredients to compound livestock feed became necessary and should be encouraged (Bello, 1988).

The most important commercial sources of plant concentrates in livestock industry are derived from groundnut, soybeans and cottonseed. Groundnut cake is a by-product of groundnut oil industry and it is one of the major oilseed cakes available in Nigeria it is the most abundant of all the plant protein concentrate (Fetuga, 1472 ), but the level of consumption of the cake is till low and the fear of Aspergillas flarus infestation resulting in mouldness, limits the utilization of the cake in momogastric nutrition (Fetuga, 1976). Also, the scarcity of groundnut cake in recent limes has caused a tremendous increase in its price. Moreover, the by-product is usually adulterated, thus resulting in poor quality finished feeds for monogastric animals, utilizing groundnut cake as the sole plant protein source.

It is therefore necessary to explore the possibility of using alternative plant protein concentrate in poultry and pig feeds to reduce cost and improve productive performance. One of such concentrate is cottonseed cake, which is locally abundant in the country. Preliminary studies on cottonseed cake obtained from local feedmiller in Ibadan indicate that it contains $36.15 \%$ protein, $19.96 \%$ fibre, $14.42 \%$ fat, while biological value was 51.0 as compared to 61.0 and 73.0 for defatted and full-fat extruded soybean meals (Bamgbose, 1995). Cottonseed cake contains gosspol, a naturally occuring polyphenolic factor in cottonseed, which influence the nutritional value of cottonseed cake for non-ruminants (Lipstein and Bornstein, 1964; Ikurior and Fetuga, 1985), 
TABLE 1: COMPOSITION OF BROILER STARTER AND FINISHER GNC/CSC DIETS $(\mathrm{g} / \mathrm{Kg})$.

\begin{tabular}{|c|c|c|c|c|c|c|c|}
\hline & \multirow{3}{*}{$\begin{array}{l}0 \% \mathrm{~S} \\
1\end{array}$} & \multicolumn{2}{|c|}{ STAKTER (S) } & \multirow[t]{3}{*}{$\mathbf{E}$} & \multirow{3}{*}{$\begin{array}{l}\mathbf{T} \\
0 \% \mathbf{F} \\
1\end{array}$} & \multicolumn{2}{|c|}{ FINISHER (F) } \\
\hline & & \multirow{2}{*}{$\begin{array}{l}\mathbf{5 0 \% S} \\
2\end{array}$} & $100 \% \mathrm{~S}$ & & & \multirow{2}{*}{$\begin{array}{l}\mathbf{5 0} \% \mathrm{~F} \\
2\end{array}$} & \multirow{2}{*}{$\begin{array}{c}100 \% \mathrm{~F} \\
3\end{array}$} \\
\hline & & & 3 & & & & \\
\hline Maize & 562.5 & 562.5 & 562.5 & & 562.5 & 562.5 & 562.5 \\
\hline${ }^{*} \mathrm{GiNC}$ & 230.0 & 130.0 & - & & 150.0 & 90.0 & - \\
\hline$+\mathrm{CSC}$ & - & 130.0 & 290.0 & & 0 & 90.0 & 210.0 \\
\hline Meat meal & 50.0 & 50.0 & 50.0 & & 50.0 & 50.0 & 50.0 \\
\hline Wheat offal & 1213.0 & 90.0 & 60.0 & & 200.0 & 170.0 & 140.0 \\
\hline Bone meal & 20.0 & 20.0 & 20.0 & & 20.0 & 20.0 & \\
\hline Oyster shell & 10.0 & 10.0 & 10.0 & & 10.0 & 10.0 & 10.0 \\
\hline Premix & 5.0 & 5.0 & 5.0 & & 5.0 & 5.0 & 5.0 \\
\hline Sialt & 2.5 & 2.5 & 2.5 & & 2.5 & 2.5 & 2.5 \\
\hline (alculated M.J. (MJ/kg) & 12.10 & 12.112 & 11.85 & & 11.89 & 11.85 & 11.77 \\
\hline \multicolumn{8}{|c|}{ Determined (JM-basis) g/kg } \\
\hline (rude protein & 218.5 & 213.8 & 209.0 & & 192.5 & 189.8 & 186.8 \\
\hline ('rud: fibre & 34.1 & 42.1 & 55.0 & & 38.5 & 44.0 & $\$ .3 .1$ \\
\hline Itlier extract & 41.1 & 39.1 & 38.2 & & $40,1\}$ & 34.8 & 31.8 \\
\hline C'alcium & 13.6 & 1.3 .5 & 13.3 & & 13.0 & 1.3 .1 & 12.7 \\
\hline Phesphorus & 7.3 & 7.35 & 8.1 & & 7.1 & 7.3 & 7.9 \\
\hline Irec gessyper & $(1.1 \mathrm{k})$ & 0.17 & 0.31 & & (t). (y) & 0.14 & 0.25 \\
\hline Available lysic & 7.0 & 7.4 & 7.9 & & 6.4 & 7.11 & 7.6 \\
\hline Avaliable methionine & 2.9 & 3.1 & 3.2 & & 2.8 & 3.0 & 3.2 \\
\hline
\end{tabular}

(iNC contains ( $\mathrm{y} / \mathrm{kg}, 44.6$ protein, 50.0 filure, 90.0 fat, 40.0 ash, 1.3 calcium, 1.30 phesphorus, 34.0 avaiahle lysine. 6.0 available methisnine and $00.6,7 \mathrm{M} . \mathrm{J} / \mathrm{kg} \mathrm{M} . \mathrm{I}$ :

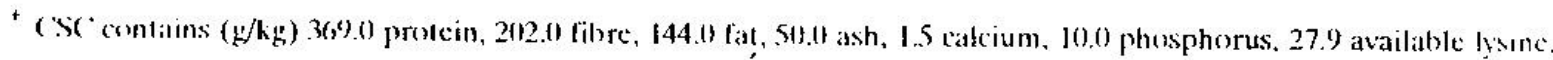

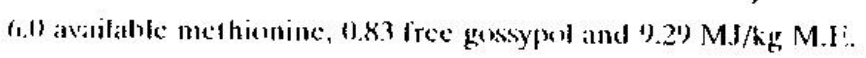

thus limiting the use of this feedstulf to mainly ruminant leeding.

The oljective of this study is lo cvaluate the effect of replacing groundnut cake (GN(') with coflonseed ake (CSO) in diets for broilers on performance, carcass characteristics and gut morphology.

\section{MATERIALS AND METIIODS}

\section{Experimental animals and diets}

A total of live hundred and forly day-sld Cobh chicks were used and hirds were randomly assigned to three experimental diets that represents the treatments at the starter phase. They were divided inte six replicates of nimety birds each. At the finisher phase, birds were assigned to nine treatmonts in a $3 \times 3$ factorial design comprising of ejghtecn replicates with thrity bircks sach. The cottonseced cake was used to replace groundnut cake at 0,50 and $100 \%$, kets. In absolute terms, coltonseed cake constituted 0 , 13 and $2 \% \%$ (starter diets $1,2,3$ ) and 0,9 and $21 \%$ (finisher diets, 1, 2, 3). The birds were reared on concrete-flowed pens with woodshaving as litter and were fed and watered ad libitum under identical environmental and management condition. 


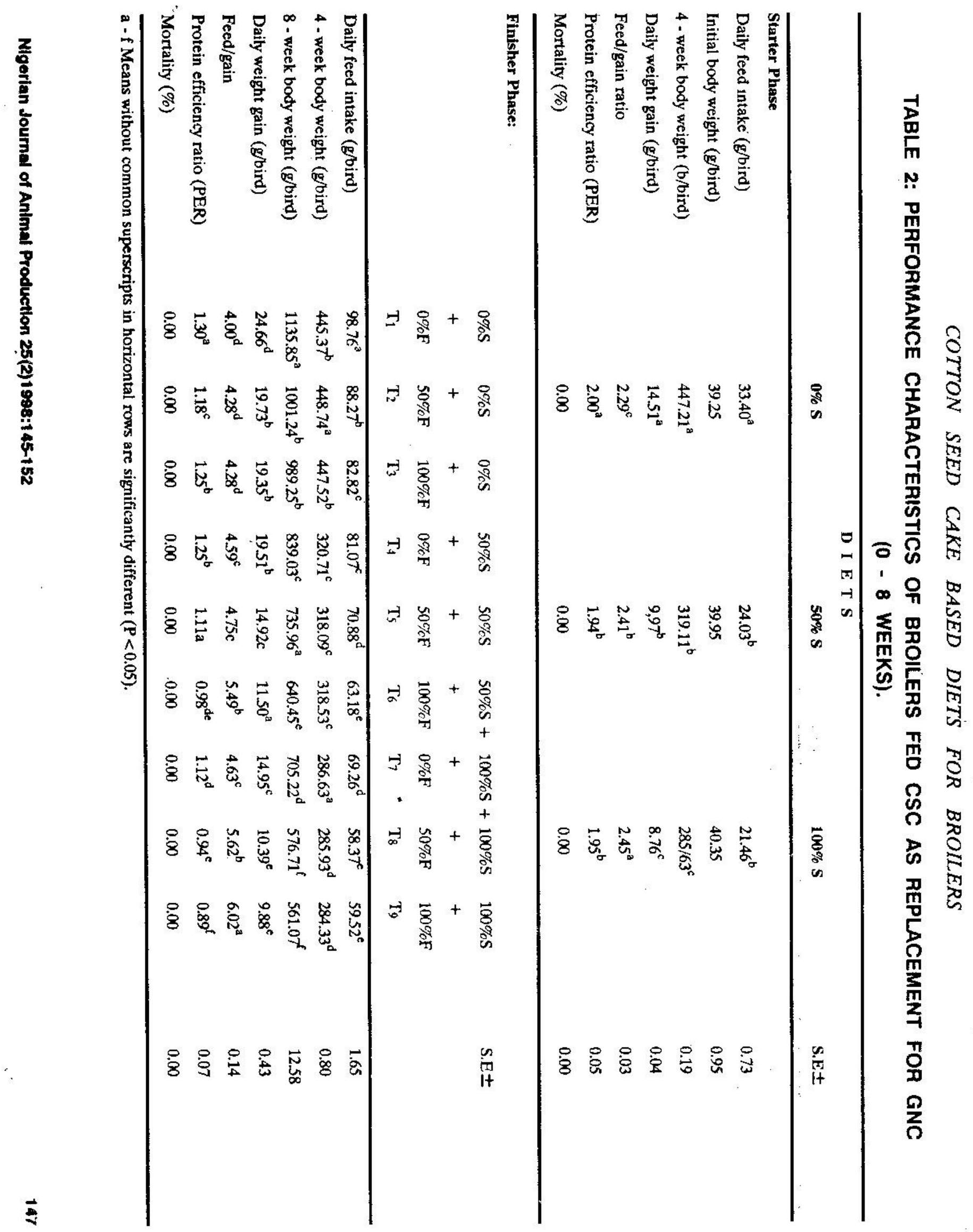




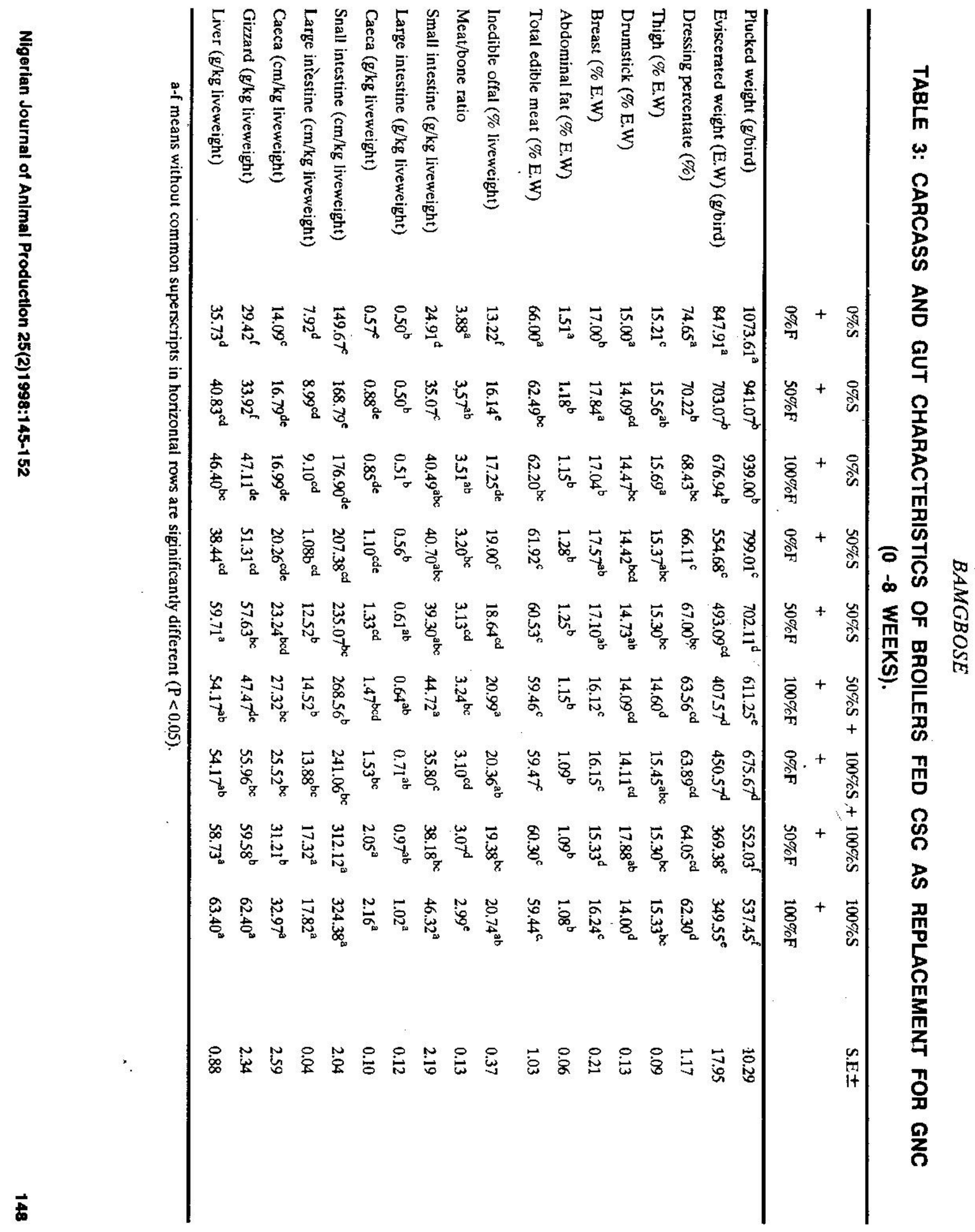




\section{COTTON SEED CAKE BASED DIETS FOR BROILERS}

Routine vaccination and medication were administered appropriately during the 56 days feeding trial.

\section{Performance and carcass measurements}

The birds were weighed at the commencement of the experiment and subsequently at weekly intervals. Records of mortality and feed consumption were also kept. On the 57 th day, ten birds per replicate were randomly selected for carcass and gut evaluation. The birds were fasted overnight but had access to water. They were weighed the following morning before slaughtering by the external cut throat method and thoroughly bled. The carcasses were defeathered, eviscerated and cleaned. The organs were carefully removed and weighed. The carcass was then cut into different parts and weighed. Weight of raw edible meat was obtained by careful removal of all muscles from the bones. Measurements of the lengths and weights of small intestine, large intestine and cacca were: recorded including weight of gizzard and liver.

\section{Chemical and statistical analyses}

All experimental diets, cottonseed cake and groundnut cake were subjected to proximate analysis according to the methods of A.O.A.C. (1984) while the method outlined by A.O.C.S. (1985) was used to determine the free gossypol contents. Available lysine was determined by the method outlined by Booth (1971) which involved the use of 2,4 - dinitro-fluoro benzene (DNFB) while available methionine determination involved preliminary enzymatic hydrolysis and the hydrolysates were then reacted with sodium nitroprusside as described by Pieniazck et al; (1975), the resultant coloured complex was measured colourimentrically. All data were subjected to analysis of variance (ANOVA) by the methods of Steel and Torrie (1960), while Duncan's multiple range test (Duncan, 1955) was used to estimate differences between treatment means.

\section{RESULTS AND DISCUSSION}

The gross and chemical composition of experimental diets and test ingredients used in this study are presented in Table 1 . Groundnut cake (GNC) has higher crude protein $(445.0 \mathrm{~g} / \mathrm{kg})$ compared to CSC $(369.0 \mathrm{~g} / \mathrm{kg})$ while $\mathrm{CSC}$ contained higher crude fibre $(202.0 \mathrm{~g} / \mathrm{kg})$ and ether extract $(144.0 \mathrm{~g} / \mathrm{kg})$. Values of proximate composition observed for GNC and CSC were at variance with those reported by Oyenuga (1968) for GNC - 514.0 protein, 46.0 fibre, $102.0 \mathrm{fat}, 55.0 \mathrm{~g} / \mathrm{kg}$ ash and Smith and Clawson (1970) reported 428.0 protein, 160.0 fibre, $30.0 \mathrm{fat}, 50 \mathrm{~g} / \mathrm{kg}$ ash for direct solvent extracted cottonseed cake. It must be noted that the GNC and CSC used were processed via hydraulic press and the $\mathrm{CSC}$ is undecorticated. Inclusion of cottonseed cake in the experimental diets resulted in progressive decrease in the metabolisable energy and crude protein with concomitant increase in the crude fibre contents of such diets. The determined free gossypol of the diets ranged between 0.14 $0.31 \mathrm{~g} / \mathrm{kg}$ which is lower than the level of $1.31 \mathrm{~g} / \mathrm{kg}$ reported by King et al, (1962) which affected the nutritive value of cottonseed cake for monogastrics. Sure et al, (1953) noted that the content of free and bound gossypol in the cottonseed cake depends upon the initial level of gossypol in the seed, the conditions selected for the preparation of the seed prior to extraction as well as the conditions used for the extraction.

Results of the study in Table 2 , showed that the use of CSC in broiler starter diet would depress feed intake at all levels. Higher $(\mathrm{P}<0.05)$ daily feed intake was recorded in broilers fed \% CSC starter diet. Daily weight gain and 4th - week body weight of birds on the 50 and $100 \%$ CSC starter diets were lower $(\mathrm{P}<0.05)$ than the control $(0 \% \mathrm{CSC})$ diets.

It should be noted however, that $50 \%$ CSC starter diets gave better values compared to $100 \%$ CSC starter diet. Feed efficiency in terms of $\mathrm{feed} / \mathrm{g}$ in ratio and PER indicated that the CSC diets were poorly utilized at the starter phase. The low feed intake and weight gain could be attributed to fibrous and bulky nature of diets with increasing level of CSC and nutritive value of cottonseed cake affecting utilization by the birds. This result is in agreement with earlier report by Jonston 
and Watts (1964), who obtained reduced feed intake, weight gain and feed consumption per gram gain of chicks fed glandless cottonseed cake while Lipstein and Bornstein (1964) and Jones and Smith (1977) opined that gossypol had adverse effect on both growth and feed efficiency of broiler chicks and rats respectively.

Results of performance characteristics at the finisher phase showed that generally, increasing level of CSC in the finisher diets resulted in significant depression in the performances of the broilers in terms of daily feed intake, daily weight gain and final liveweight (Table 2). It was also observed that birds fed $0 \% \mathrm{CSC}$ (control) at the starter phase gave the best performance at the finisher $\left(\mathrm{T}_{1}-\mathrm{T}_{3}\right)$, while birds raised on $50 \%$ CSC starter diet gave appreciable performance at the finisher phase $\left(\mathrm{T}_{4}-\mathrm{T}_{6}\right)$. The group of birds fed $100 \%$ CSC starter diets ( $\mathrm{T}_{7}-\mathrm{T}_{9}$ ) $(0.89$ - 1.12) significantly $(P<0.05)$ gave depressed performance while those fed $50 \%$ CSC starter diets $\left(\mathrm{T}_{4}-\mathrm{T}_{6}\right)(0.92-1.25)$ were slightly lower than that of the control group fed $0 \%$ CSC starter diets $\left(\mathrm{T}_{1}-\mathrm{T}_{3}\right)(1.18$ 1.30) in terms of PER.

This result was at variance with earlier report of NAPRI (1984) that feeding cottonseed cake up to $50 \%$ in broiler diet had no significant effect on performance of broiler chickens. However, Ryan et al. (1986) observed that inclusion of cottonseed cake up to $30 \%$ in broiler diet significantly depressed feed intake and weight gain of birds. The result agrecd with the findings of Robertson (1970) that final body weight of broilers fed glandless cottonseed cake were lower than birds on soyabean meal control diet due to the combined effect of gossypol and fibre levels. The survival of all the birds during the study indicated that broilers could tolerate cottonseed cake diets despite criticism coupled with good management and that the free gossypol content is sub-lethal.

The results of carcass and gut characteristics (Table 3) showed significant difference due to the dietary treatments. The average eviscerated weight of the birds decreased significantly $(\mathrm{P}<0.05)$ with the inclusion levels of cottonseed cake, treatment 1 (with $0 \%$ inclusion) had the highest eviscerated weight of $847.9 \mathrm{~g}$ while treatment 9 had the lowest value of $349.5 \mathrm{~g}$; treatments $2-8$ gave a range of $369.4-703.1 \mathrm{~g}$. Similarly, the dressing percentage of birds on treatment 1 (74.68\%) was significantly $(P<0.05)$ higher than other treatments $(62.30-70.22 \%)$. This could be explained in part due to low feed intake on CSC diets and reduced weight gain resulting from poor utilization of such diets. It has been suggested (Narian et al., 1960) that dietary protein quality and level in diet, as well as iron supplementation in a 1:1 molar ratio to free gossypol will ensure improved broiler performance and carcass traits.

The carcass cut parts (\% eviscerated) of thigh drumstick and breast were significantly influenced by varying proportions of cottonseed cake in the broiler diets. Birds fed $100 \%$ CSC diets at the starter and finisher phases gave the least values for the cut parts. Lowest meat to bone ration was recorded with treatment 9 (2.99) compared to treatment 1 (3.88) others varied between $3.07-3.57$; since broiler chickens are efficient converters of feed, a poor dietary protein will result in poor tissue deposition, hence poor edible meat (Table 3) due in part to amino acid imbalance associated with unsupplemented CSC diets which could result in poor utilization of protein CSC. Reid et al, (1987) observed the unavailability of nutrients in heated cottonseed cake. This result agreed with the observation of Atuahene et al (1986), Susbilla et al, (1994) who reported that increasing dietary inclusion of glanded CSC in broiler diet resulted in poor carcass yield especially when the diet was not supplemented with lysine.

The increased dietary inclusion of CSC had significant $(P<0.05)$ effect on the abdominal fat pad, weights and lengths of small intestine, large intestine, caeca, gizzard and liver weights. Signilicantly higher values $(P<0.05)$ were observed for weights of gizzard, liver, small intestine, large intestine and caeca with increased CSC inclusion. This may not be unconnected with abbrassive nature of the 


\section{COTTON SEED CAKE BASED DIETS FOR BROILERS}

dietary fibre and greater volume of digesta in the gastro-intestinal tract could have caused increase in size and length of the gut parts and muscles of the gizzard (Waldroup, 1981).

Based on the results obtained with broiler chickens fed CSC at the starter and finisher phase, it was evident that inclusion of CSC at 50 and $100 \%$ replacement levels for GNC had adverse effect on performance and carcass parameters assessed; therefore in absolute terms, inclusion of CSC up to $290 \mathrm{~g} / \mathrm{kg}$ starter diet and $210 \mathrm{~g} / \mathrm{kg}$ finisher diet are not advisable; however, if desired, such diets can be blended with lysine-rich feedstuffs such as defatted or full-fat soyabean meal or supplemented with synthetic lysine for improved performance and appreciable carcass yield at the end of eight week rearing period.

\section{REFERENCES}

AMERICAN OIL CHEMISTS SOCIETY. (1985). Sampling and analysis of oilseed by-products. Official method. Ba 11 - 65.

ASSOCIATION OF OFFICIAL ANALYTICAL CHEMISTS. (1984). Official methods of analysis. 14th ed. Association of Official Analytical Chemists. Washington, D.C.

ATUAHENE, C.C., DONKOH, A. and NKANSAII-DAKO, P. (1986). Effect of raw cottonseed meal on the performance, carcass characteristics and certain blood parameters of broiler chickens. J. Anim. Prod. Res. 6(2): $107-114$.

BAMGBOSE, A.M. (1995). Chemical analysis of some oilseed cakes. Indian J. Anim. Sci. 65(12): 1341 - 1346.

BEILO, A.O. (1988). Problems confronting feedmilling industry in Nigeria and possible way out. In: National Workshop on Alternative Formulation of Livestock Feeds in Nigeria. (Ed. G.M. Babatunde), 65 - 94.

BOOTH, V.H. (1971). Problems in the determination of DNFB - available lysine. J. Sci. Ed. Agric. 22: 658 - 666.

DUNCAN, D.B. (1955). Multiple range and F-test, Biometrics. 11: 1 - 42 .

FETUGA, B.L.A. (1972). Assessment of the protein quality of certain Nigerian food and feeding stuffs on the nutrition of the pig and of the rat. Ph.D. Thesis. Department of Animal Science, University of Ibadan. Ibadan, Nigeria.

FETUGA, B.A. (1976). Animal production and feed supplies. Nig. J. Ani. Prod. 4(1): 132 - 142.

IKURJOR, S.A. and FETUGA, B.L.A. (1985). The replacement value of Nigerian cottonseed meal for groundnut cake in diets for weaner-grower pigs. Nig. J. Anim. Prod. 12(1): 13 - 19.
JONES, L.A. and SMITH, F.H. (1977). Effect of bound gossypol and amino acid supplementation of glandless cottonseed on the growth of weaning rats. J. Ani. Sci. 44: $401-409$.

JONSTON, C. and WATTS, A.B. (1964). The chick feeding value of meals prepared from glandless cottonseed, Poult. Sci. 43: 957 - 959.

KING, W.H., KUCK, J.C. and FRAMPTON, V.L. (1962). Lysine, gossypol and nitrogen solubility in chemically treated cottonseed meals. J.Ani, Oil Chem. Soc. 39: 58 $-60$.

LIPSTEIN, B. and BORNSTEIN, S. (1964). Studies with acidulated cottonseedoil soapstock. 2. Attempts to reduce its gossypol content. Brit. J. Sci. 43: 694 - 701.

NARIAN, R, LYMAN, C.M., DEYOE, L.W. and COUCH, J.R (1960). Effect of protein level of the diet on free gosspol tolerance in chicks. Poult, Sci. 39: 1556 - 1560.

NATIONAL ANIMAL PRODUCTION RESEARCH INSTITUTE (1984). Highlights of research achievements on animal feeds. Federal Ministry of Education, Science and Technology, Lagos. 12 - 14.

OYENUGA, V.A. (1968). Nigeria Feed and Feeding-stuffs. Their chemistry and nut ritive values. Ibadan University Press. Ibadan, Nigeria (3rd ed.).

PIENIAZEK, D., RAKOWSKA, M. and KUNACHOWKZ, H. (1975). The participation of methionine and cystine in the formation of bond resistant to the action of proteolytic enzymes in heated casein. Brit. J. Nutr. 34: $163-165$.

REID, B.L., GAIAVIZ-MORENO, S. and MAIORINO, P.M. (1987). Evaluation of isopropanol - extracted cottonseed meal for laying hens. Poult. Sci. 66: 82 - 89.

ROBER'ISON, R.H. (1970). A comparison of glandless cottonseed meal and soyabean meal in broiler and laying dict supplemented with lysine and methionine. Poult. Sci. 49: $1579 \cdot 1586$.

RYAN, J.R, KRATZER, F.H. GRAU, C.R. and VOHRA, P. (1986). Glandless cottonseed meal for laying and breeding hens and broiler chicks. Poult. Sci. 65: 949 - 955.

SMITH, F.W. and CLAWSON, A.J. (1970). Effects of dietary gossypol in animals. J. Am. Oil. Chem. Soc. 47: $443-447$.

STEEL, R.G.D. and TORRIE, J.H. (1960). Principles and procedures of statistics. A biometrical approach. McGraw Hill Book Company, Inc. New York.

SURE, B., EASTERLING, L, DOWELL, J. and CRUDUP, M. (1953). Cottonseed cake. The influence of processing on protein values. J. Agric. Fd. Chem. 1: $82-84$

SUSBILLA, J.P., FRANKEL, T.L., PARKINSON, G. and GROW, C.B. (1994). Weight of internal organs and carcass yield of early feed restricted broilers. Brit. J. Sci. 35: $677-685$.

WALDROUP, P.W. (1981). Cottonseed meal in poultry diets. Feedstuffs. 53(52): $21-24$. 